\title{
Geotechnical evaluation of gully erosion and landslides materials and their impact in Iguosa and its environs, southern Nigeria
}

\author{
Godwin Okumagbe Aigbadon ${ }^{*}$ (D), Azuka Ocheli ${ }^{2}$ and Ernest Orji Akudo
}

\begin{abstract}
Background: Detailed field surveys and geotechnical evaluation of soils in Iguosa and its environs, Southern Nigeria, were undertaken to determine the root causes, mechanisms, and impacts of landslides and gully erosion. This was done to suggest appropriate mitigation measures to reclaim the affected land and prevent future occurrences in the study area.

Results: Field study revealed high elevations, a steep slope, high rainfall and inadequate drainage systems. Also, human activities and socio-cultural activities have contributed to the large lateral extents in depths and widths of the landslides and gullies in the study area. The geotechnical analyses reveal that soil samples from SB1, SB2, SB6 and SB7 lithological units are mainly sandy clay with a coefficient of permeability ranging from $3.5 \times 10^{-4}$ to $4.2 \times 10^{-4} \mathrm{~cm} / \mathrm{s}$, the cohesion ranges from 27 to $28 \mathrm{kpa}$ and angle of internal resistance ranges from $27^{\circ}$ to $30^{\circ}$ respectively. The plastic limit ranges from 2 to 4 , and liquid limit ranges from 33 to 38, and the plasticity index ranges from 30 to 36 . Ajali sand units SB3, SB4, SB8 and SB9, consist of coarse-grained sand with no plasticity. The coefficient of permeability ranges from $2.8 \times 10^{-4}$ to $3.2 \times 10^{-4} \mathrm{~cm} / \mathrm{s}$, the cohesion range from 10 to $18 \mathrm{kpa}$, angle of internal resistance $24^{\circ}$ to $26^{\circ}$, respectively. The soil samples from SB5 and SB10 lithological units are silty-clay with a coefficient of permeability of $4.6 \times 10^{-4}$ to $4.8 \times 10^{-4} \mathrm{~cm} / \mathrm{s}$. The cohesion of 45 to $46 \mathrm{kpa}$, and angle of internal resistance of $37^{\circ}$ to $40^{\circ}$, respectively. The plastic limits ranges from 35 to 36, and liquid limit is 76 , and the plasticity index ranges from 40 to 41 .

Conclusion: Field survey and geotechnical evaluations of the soils revealed that high elevation, a steep slope and the geotechnical properties of the soils were the initial conditions that initiated landslides and gully developments in the study area. This has also been influenced by rainfall, poor vegetation, inadequate drainage systems, and human activities as well as socio-cultural activities. Over four hundred and thirty-two houses and farmlands and other properties have been damaged and abandoned in the study area. Covering the landslide areas with impermeable layers/ materials, diverting surface water away from the landslide areas, enacting laws to prevent the erection of structures on landslide prone-areas, sound drainage systems, the use of biotechnical slope and bioengineering methods, afforestation and re-vegetation were the proposed mitigation measures to tackle this menace in the study area.
\end{abstract}

Keywords: Geotechnical survey, Landslides, Plasticity, Cohesion, Permeability, Slope, Sandy-clay

${ }^{*}$ Correspondence: godwin.aigbadon@yahoo.com

1 Department of Geology, Faculty of Sciences, Federal University Lokoja,

Lokoja, Kogi, Nigeria

Full list of author information is available at the end of the article

\section{Background}

Landslide is one of the major landscape disasters that has damaged buildings and other physical properties worth millions to billions of dollars annually during the rainy seasons (Igwe 2015). Cruden and Varnes (1996), Iverson (2000), Jakob et al. (2006), Yalcin (2007), Igwe and Fukuoka (2010), Msilimba and Holmes (2010), Wang 
et al. (2002), Sassa et al. (2004), Guzzetti et al. (1999), Igwe (2015), Igwe and Una (2019) conducted study on mechanisms associated with rainfall-induced landslides and these have been well documented. They are of the opinion that Intense and prolonged rainfalls, degree of slopes, discontinuities, weathering, and flooding are the major factors predisposing landslides globally. Brand et al. (1984) believed that most landslides and erosional activities in Hong Kong were rainfall-induced either as concentrated or short-duration rainfall of high intensity. Koko and Chowdhury (2005) had similar observations that the landslides and gully erosion and the associated risk correlated with rainfall-induced landslide along the railway of high slope angles ranging from $32^{\circ}$ to $42^{\circ}$. Sikdar et al. (2004) worked on the Raniganj coal mining area of Western Bengal and found out that the degree of slope within the study area varies from $0^{\circ}$ to $15^{\circ}$. It shows that the slope of the area ranges from very gentle to moderate slope. Chen et al. (2012a, b) attributed the 2008 Wenchuan earthquake to have occurred on areas with slope angles varying from $30^{\circ}$ to $50^{\circ}$. The heavy rainfall mechanism associated with long run-out triggered the 'August 1998' landslides in Fukushima Prefecture, Japan. The affected inhabitants of these affected areas were relocated to a more stable environment. In West African countries, landslides are caused primarily by rainfall (Igwe 2015). In recent times, Nigeria has witnessed a high frequency and variation of landslides and erosional activities caused by geological settings. Ayodele et al. (2020) conducted geological assessment of landslide occurrences in the Okemesi area in southwestern Nigeria to determine the geotechnical properties of the soils. They concluded that the rocks in Okemesi were intensely fractured and thus contributed to the occurrence of landslides in Okemesi. The prolonged rainfall of October 2013 initiated twentyeight (28) new shallow landslides and gully erosion in the Enugu and Obudu area around Calabar, which resulted in several casualties and severe economic loss (Igwe 2015). Ogbukagu (1976), Varnes (1978), Egboka and Okpoko (1984), Okagbue (1986, 1992), Igwe et al. (2013), Igwe (2015), Egboka et al. (2019), Ocheli et al. (2021) carried out detailed studies on landslides and gully erosion in Nanka and other parts of Anambra Basin, Southeastern Nigeria, using field campaigns and geotechnical techniques in many learned journals. Ocheli et al. (2021) carried out detailed studies on geology and geotechnical investigations of Anambra Basin, Southern Nigeria using field and various laboratory techniques. They found that gully erosions have been developing on steep slopes and non-vegetated areas. The genesis of the gullies was accelerated by the cohesionless and very permeable nature of the sand formations. The impacts and mitigation measures of landslides in the Nanka area of Anambra Basin were carried out using field monitoring, laboratory analyses and limit equilibrium simulations. The study also shows that the topography of the Nanka areas have been negatively affected by landslides and gully erosion. They revealed that the landslides and gully erosion was caused by factors like; water infiltration, high slope gradient, and poorly consolidated and non plastic sands. These sands were overlain by the less permeable silt-clay units. The ground is continuously saturated with water whenever there is torrential rainfall. Torrential rainfall often led to the build up of water pressure within a perched aquifer, which reduces the shear strength and cohesion of the soil and ultimately initiates landslides and gully erosion (Fukuoka 1980; Wieczorek 1996; Li et al. 2005; Lee et al. 2012; Igwe et al. 2013). Despite the fact that various mitigation measures recommended and adopted by many scholars, including the provision of sufficient drainage systems in an area of slope failures (Highland and Bobrowsky 2008), biotechnical slope techniques, and soil bioengineering method (Gray and Leiser 1982; Gray and Sotir 1996) and the use of bamboo trees as demonstrated in some parts of Oko and Amucha in Southeastern Nigeria (Igwe and Una 2019), the incidence of landslides and gully erosion have continued to occur and reoccur in different parts of Nigeria. Omon and Ogheruemusua (2014) have evaluated soil erosion in the Benin metropolis, Edo State, and found out that rain is the main cause of soil erosion followed by soil character, and thus recommended construction of side drains and tunnels. The outcomes of these recommended measures employed in the study area remain unsuccessful, as landslides and gully erosions have continued to occur and reoccur at a very high magnitude, with over four hundred and thirty-two houses and farmlands damaged and abandoned. Detailed information about the root causes, mechanisms, and the continuous landslides and gully erosion in the study area is relatively lacking. The objective of this study is to identify the root causes, mechanisms and impact of landslides in the study area. In addition, regarding landslides and gullies studies in the study area, there is no existing research work of such magnitude has been done. Effective mitigation measures shall be suggested to reclaim the affected land and avoid future occurrences and reoccurrences of these disasters in the study area.

\section{Location and climatic conditions}

The study area in Southern Nigeria, is between latitudes $6^{\circ} 20^{1} \mathrm{~N}$ and $6^{\circ} 50^{1} \mathrm{~N}$ and longitudes $5^{\circ} 40^{1} \mathrm{E}$ and $5^{\circ} 00^{1} \mathrm{E}$, respectively (Fig. 1). The study area has two distinct seasons; the rainy and the dry seasons. The rainy season begins in April and stops in October, while the dry season begins in November and ends around March. The study area has a total annual rainfall range of $1600-2220 \mathrm{~mm}$ 


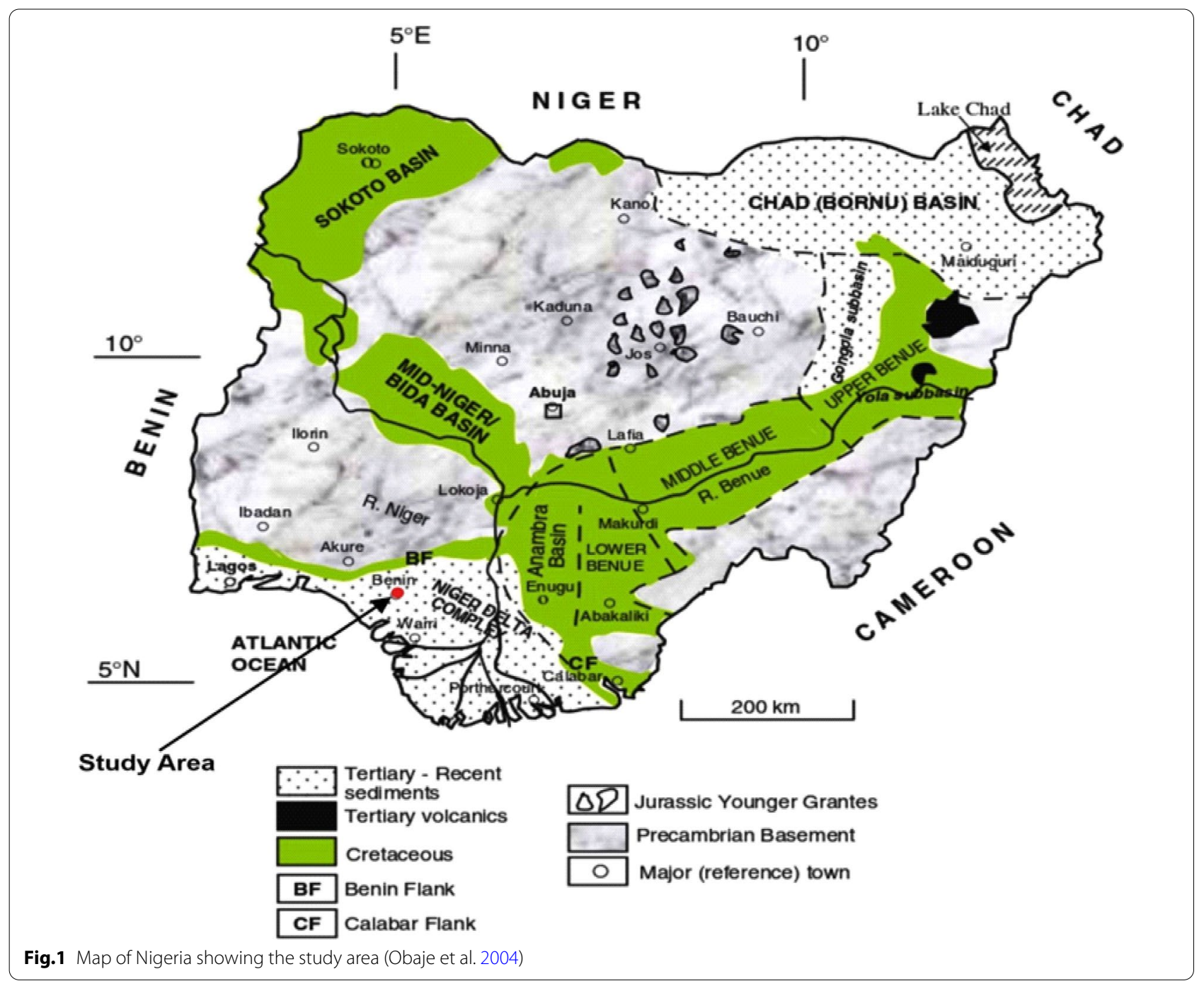

(Nimet 2010; Ukhurebor and Abiodun 2018). The mean monthly temperature during the rainy season ranges from 20 to $28{ }^{\circ} \mathrm{C}$ (Nimet 2010), and the mean monthly temperature during the dry season ranges from 28 to $33{ }^{\circ} \mathrm{C}$ (Nimet 2010; Ukhurebor and Abiodun 2018), respectively. The areas of study are within the tropical rainforest belt and are mainly of trees and shrubs.

\section{Geology of the study area}

The geology of the study area comprises quaternary deposits, Benin Formation, Ajali sands, and OgwashiAsaba Formation. Kogbe (1976) classified OgwashiAsaba Formation as gritty sands, clay, and lignite seam with clay intercalations of continental depositional setting. Reyment (1965), Kogbe (1976) gave the age as Miocene to Recent. Akujieze (2004) stated that it is exposed at the stream channels of the Northern part of the Benin area towards the west of Ekiadolor-Iwu, Utekon and North Azalla.

The Benin Formation comprises of top reddish to brown lateritic soil, clay, very coarse to coarse, very poorly to poorly sorted sands, and sometimes ferruginous sandstone, gravels, and netlike mud cracks. The thickness ranges from $800 \mathrm{~m}$ thick around Benin City to $1830 \mathrm{~m}$ towards the sea (Ikhile 2015). The environment of deposition is mainly continental (Short and Stauble 1967; Evamy et al. 1978; Weber and Daukoru 1978). The red earth sand is coastal plain environments that are exposed in Owerri, Calabar, Onitsha, and Benin Region. The age of the Benin Formation ranges from Oligocene to Pleistocene.

The Quaternary deposits of the study area are mainly alluvium deposited on the flood plains of Ovia and 
Ikpoba. They are primarily reddish to brownish-white sands, silts, clayey sands, and gravels.

\section{Materials and methodology}

The primary information used in this study includes field campaigns, photographs of landslides and gullies, field measurements, generated maps, and interpretations from the result of geotechnical soil indices. Thematic maps of 3-D topographic elevation model slope and land use was produced using remote sensing data with the aid of Arc GIS 10.50 software to ascertain areas vulnerable to landslides and gullies in the study area. The 3D topographic elevation, slope and land use map was produced using Shuttle Radar Topographic Mission (SRTM- $30 \mathrm{~m}$ data) and Enhanced Topographic Mapper Plus (ETM+) data collected from the USGS website.

The landslides in the study area were described and classified according to (Cruden and Varnes 1996; Perucca et al. 2009). In the study area the magnitude/degree of the landslides was evaluated from the crown to the toe of the rapture. The exact location of gullies and landslides in the field was determined with the Global Positioning System (GPS). Ten samples were collected at sidewalls, slide floors of the landslides and gullies, respectively and welllabeled at the point of collection. The GPS readings were taken at this point of samples collections at landslides and gully locations. Each soil was collected by driving the hand auger to a plough depth of $15 \mathrm{~cm}$ to draw the soil samples. These samples were collected from the topsoil $(15 \mathrm{~cm})$ by removing the topsoil, slide walls and the slide floors, respectively. Each collected samples were labelled correctly, wrapped carefully with newspapers and placed in each polythene bags before taking them to the laboratory for further analysis.

The depths, length, width, lateral extent of the slides were measured using measuring tapes. The slope angles and the elevations of the gullies and slides in the study areas were measured with a clinometer and Global Positioning System (GPS) respectively. The limitations of study were the presences of thick vegetation, steep and deep gullies and rugged terrains that made the accessibility and sample collections challenging.

\section{Geotechnical analyses}

A set of British Standard sieve of various diameters $4.875 \mathrm{~mm}, 3.55 \mathrm{~mm}, 2.36 \mathrm{~mm}, 1.18 \mathrm{~mm}, 600 \mu \mathrm{m}, 425 \mu \mathrm{m}$, $300 \mu \mathrm{m}, 150 \mu \mathrm{m}, 75 \mu \mathrm{m}$ with a receiver pan were used to carry out the sieve analysis to determine the percentage retained on each sieves using the procedures described by the British standard (1990) methods as also explained by other authors (Ishaque et al. 2010; Ocheli et al. 2021). $50 \mathrm{~g}$ of each soil samples were washed and oven-dried and after that passed through the set of sieves. The atterberg limits comprising liquid limit tests and the plastic limit tests was carried out according to (British Standard 1990; Ishaque et al. 2010). The liquid limit test were performed using Casagrande grooving device to groove $50 \mathrm{~g}$ of each soil samples, and the plastic limit of each $50 \mathrm{~g}$ soil samples was roll out in a thread of the $50 \mathrm{~g}$ of soil samples on a flat, non-porous surface with the aim of evaluating the behavioural characteristics of the soils (Ocheli et al. 2021). The plastic limit test was performed under the methodology described by the British Standard Method for Testing Soils (B.S. 1990). Sohne (1953), Ocheli et al. (2021) determine the shear strength of the soils using a vane shear apparatus as described. The significance is to determine the values for cohesion and angle of internal resistance between the grains, respectively. Munch and Douglas (1985), BS 1377.5 (1990) determine the permeability of the soil using the constant head permeability test.

\section{Results and discussion \\ Results of the field study}

From Table 1, the result of the elevation of the study area ranges from 22.86 to $332.0 \mathrm{~m}$, with a mean elevation of $183.11 \mathrm{~m}$. Lateral extent ranges from 40.2 to $93.0 \mathrm{~m}$ with a mean value of $87.3 \mathrm{~m}$. The depth ranges from 2.6 to $68.7 \mathrm{~m}$ with a mean value of $57.07 \mathrm{~m}$. The width ranges from 20.4 to $72.6 \mathrm{~m}$ with a mean value of $32.24 \mathrm{~m}$. The slope steepness (angle of a slope) range from $7^{\circ}$ to $32^{\circ}$ with a mean value of $20.25^{\circ}$. Slope values as classified (Sikdar et al. 2004; Ocheli et al. 2021), indicates that values of $<0.5^{\circ}$ indicates very gentle slope, $5<10^{\circ}$ indicates gentle slope, $10<15^{\circ}$ indicates moderate slope, $15<25^{\circ}$ indicates moderately steep slope, $25<35^{\circ}$ indicates steep slope and, $>35.0^{\circ}$ indicates a very steep slope. Based on the results obtained in (Table 1), which ranges from $7^{\circ}$ to $32^{\circ}$, compared with the class and description of slopes (Sikdar et al. 2004; Ocheli et al. 2021), the degree of steepness of the study area falls within an interval of gentle to a steep slope. The frequency of the slopes is shown in Table 2. The generated digital elevation model, slope map, and land use map of the study area from $30 \mathrm{~m}$ data-Spatial Resolution and Shuttle Radar Topographic Mission (SRTM) are captured (Figs. 2, 3, 4). It shows that the elevation, the steepness of the slope, and poor land contributed to the landslides and gullies in the study area. Other factors which contributed to continuous land sliding and gullies in the area are run-off from heavy downpour and infiltration, deforestation, overgrazing, and flawed drainage system. During the early stage of land-sliding and gullying activities, the lateral extent and width of the slides were not initially proportionate. As the landslides and gullies become rapid, the lateral extent of the sliding becomes relatively proportional to 
Table 1 Field measurements for gullies and slides in the study area

\begin{tabular}{|c|c|c|c|c|c|c|c|c|}
\hline $\mathrm{S} / \mathrm{N}$ & Longitudes (E) & Latitudes (N) & Elevations (m) & Lateralextents (m) & Depth (m) & Width (m) & Slopeangle $\left(^{\circ}\right)$ & Description of slope \\
\hline 1 & $05^{\circ} 41^{\prime} 23^{\prime \prime}$ & $06^{\circ} 27^{\prime} 40^{\prime \prime}$ & 332.00 & 80.0 & 68.7 & 23.2 & 32 & Steepslope \\
\hline 2 & $05^{\circ} 37^{\prime} 43^{\prime \prime}$ & $06^{\circ} 29^{\prime} 41^{\prime \prime}$ & 310.80 & 40.2 & 68.2 & 20.4 & 31 & Steepslope \\
\hline 3 & $05^{\circ} 43^{\prime} 16^{\prime \prime}$ & $06^{\circ} 28^{\prime} 32^{\prime \prime}$ & 306.00 & 80.0 & 66.9 & 28.4 & 20 & Moderately steepslope \\
\hline 4 & $05^{\circ} 40^{\prime} 10^{\prime \prime}$ & $06^{\circ} 28^{\prime} 30^{\prime \prime}$ & 200.40 & 73.0 & 66.3 & 31.6 & 18 & Moderately steepslope \\
\hline 5 & $05^{\circ} 12^{\prime} 13^{\prime \prime}$ & $06^{\circ} 24^{\prime} 00^{\prime \prime}$ & 120.00 & 64.0 & 64.7 & 30.4 & 16 & Moderately steepslope \\
\hline 6 & $05^{\circ} 13^{\prime} 13^{\prime \prime}$ & $06^{\circ} 04^{\prime} 14^{\prime \prime}$ & 118.60 & 93.0 & 67.0 & 33.8 & 13 & Moderateslope \\
\hline 7 & $05^{\circ} 32^{\prime} 07^{\prime \prime}$ & $06^{\circ} 32^{\prime} 00^{\prime \prime}$ & 58.40 & 69.4 & 67.1 & 33.7 & 10 & Moderateslope \\
\hline 8 & $05^{\circ} 12^{\prime} 18^{\prime \prime}$ & $06^{\circ} 37^{\prime} 01^{\prime \prime}$ & 26.30 & 80.2 & 20.3 & 72.6 & 09 & Gentleslope \\
\hline 9 & $05^{\circ} 37^{\prime} 13^{\prime \prime}$ & $06^{\circ} 25^{\prime} 00^{\prime \prime}$ & 24.70 & 50.2 & 4.1 & 46.7 & 07 & Gentleslope \\
\hline 10 & $05^{\circ} 35^{\prime} 00^{\prime \prime}$ & $06^{\circ} 27^{\prime} 01^{\prime \prime}$ & 22.86 & 43.0 & 2.6 & 30.4 & 07 & Gentleslope \\
\hline 11 & $05^{\circ} 32^{\prime} 13^{\prime \prime}$ & $06^{\circ} 24^{\prime} 00^{\prime \prime}$ & 120.00 & 64.0 & 60.7 & 40.4 & 16 & Moderately steepslope \\
\hline 12 & $05^{\circ} 34^{\prime} 00^{\prime \prime}$ & $06^{\circ} 27^{\prime} 01^{\prime \prime}$ & 118.60 & 93.0 & 65.0 & 34.8 & 13 & Moderately steepslope \\
\hline 13 & $05^{\circ} 37^{\prime} 13^{\prime \prime}$ & $06^{\circ} 28^{\prime} 32^{\prime \prime}$ & 306.00 & 80.0 & 66.9 & 28.4 & 20 & Moderately steepslope \\
\hline 14 & $05^{\circ} 41^{\prime} 30^{\prime \prime}$ & $06^{\circ} 27^{\prime} 40^{\prime \prime}$ & 200.40 & 73.0 & 64.3 & 32.6 & 18 & Moderatelysteepslope \\
\hline 15 & $05^{\circ} 52^{\prime} 13^{\prime \prime}$ & $07^{0} 34^{\prime} 00^{\prime \prime}$ & 120.00 & 64.0 & 64.7 & 32.4 & 16 & Moderately steepslope \\
\hline 16 & $05^{\circ} 37^{\prime} 40^{\prime \prime}$ & $06^{\circ} 26^{\prime} 30^{\prime \prime}$ & 332.0 & 80.0 & 60.7 & 24.2 & 32 & Steepslope \\
\hline 17 & $05^{\circ} 3813^{\prime \prime}$ & $06^{\circ} 25^{\prime} 00^{\prime \prime}$ & 310.80 & 40.2 & 68.4 & 20.4 & 31 & Steepslope \\
\hline 18 & $05^{\circ} 43^{\prime} 16^{\prime \prime}$ & $06^{\circ} 38^{\prime} 32^{\prime \prime}$ & 308.00 & 80.0 & 66.9 & 30.4 & 32 & Steepslope \\
\hline 19 & $05^{\circ} 44^{\prime} 10^{\prime \prime}$ & $06^{0} 38^{\prime} 30^{\prime \prime}$ & 204.40 & 73.0 & 64.3 & 32.6 & 32 & Steepslope \\
\hline \multirow[t]{2}{*}{20} & $05^{\circ} 45^{\prime} 13^{\prime \prime}$ & $06^{\circ} 40^{\prime} 00^{\prime \prime}$ & 122.00 & 64.0 & 63.7 & 30.4 & 32 & Steepslope \\
\hline & & & MEAN $=183.11$ & MEAN $=87.30$ & $\mathrm{MEAN}=57.07$ & $\mathrm{MEAN}=32.24$ & MEAN $=20.25$ & $\begin{array}{l}\text { Remarks: gentle steep- } \\
\text { slopes }\end{array}$ \\
\hline
\end{tabular}

Table 2 Frequency of slope angles of the slides and gullies in study area (2020-2021)

\begin{tabular}{ll}
\hline Slopes angles of the landslides $\left(^{\circ}\right)$ & $\begin{array}{l}\text { Frequency of } \\
\text { the landslides }\end{array}$ \\
\hline $7^{\circ}$ & 2 \\
$9^{\circ}$ & 1 \\
$10^{\circ}$ & 1 \\
$13^{\circ}$ & 2 \\
$16^{\circ}$ & 3 \\
$18^{\circ}$ & 2 \\
$20^{\circ}$ & 2 \\
$31^{\circ}$ & 2 \\
$32^{\circ}$ & 5 \\
\hline
\end{tabular}

the slope angles of the landslides (Fig. 5a). From Fig. 5b, the blue colour shows the initial stage of the sliding as a very gentle to gentle slope. The red colour shows the advanced stage of sliding from a moderately steep slope to a steep slope in the study area. As the width of landslides increases, the lateral extent of the landslides relatively increases, and these occur more on the slope angles of $22.5^{\circ}$ and elevations of $183.11 \mathrm{~m}$. From the plot of the dimensions of the landslide against the slope angles of the landslides (Fig. 5a). The elevation, width, and depth values of the landslides and gullies indicate that the sliding is almost at the same rate. These sliding activities are prominently trending in the northeast direction of the study area (Fig. 5b, c). The lithological study revealed that the topmost layer of the gully profile consists of dense lateritic soil, underlain by Ajali sands and then some clay materials at the slide walls and floor of the slides/gullies. The Ajali sand is primarily medium to coarse-grained, friable, and unconsolidated sands of $250 \mathrm{~cm}$ thickness in the landslides area. Also, within the landslide areas, the units are inter-bedded by clay and silty soils. The photographs of some of the landslides and gullies in the study area are displayed (Fig. 6a-e).

\section{Result of geotechnical analyses}

The result of the soil samples (Table 3) collected from the landslides and gully prone areas shows that soil samples SB1, SB2, SB6, and SB7 are mainly sandy clay with a coefficient of permeability ranging from $3.5 \times 10^{-4}$ to $4.2 \times 10^{-4} \mathrm{~cm} / \mathrm{s}$, cohesion ranging from 27 to $28 \mathrm{kpa}$ and angle of internal resistance ranging from $27^{\circ}$ to $30^{\circ}$ respectively. Surenda and Sajeev (2017) classified angles of internal resistance between grains as: $<28^{\circ}$ shows very loose compaction, $\geq 28^{\circ}-30^{\circ}$ displays loose 


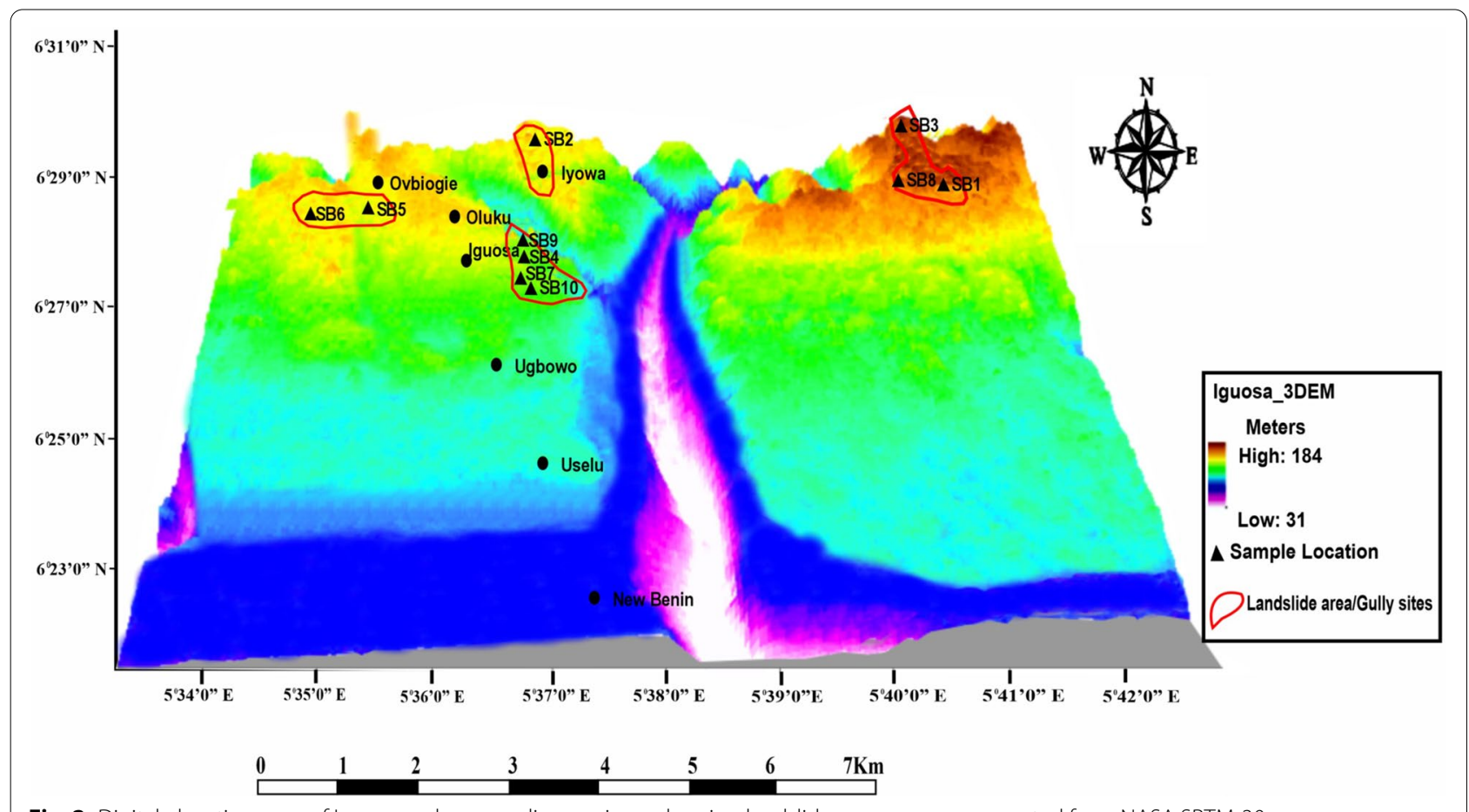

Fig. 2 Digital elevation map of Iguosa and surrounding environs showing landslides prone areas generated from NASA SRTM-30 m

compaction, $\geq 30^{\circ}-36^{\circ}$ indicates medium compaction, $\geq 36^{\circ}-41^{\circ}$ indicate dense compaction, $\geq 41^{\circ}$ shows very dense compaction. From Surenda and Sajeev (2017), it shows that soil samples from these lithological units range from very loose compaction to loose compaction. The plastic limit ranges from 2 to 4 , and liquid limit ranges from 33 to 38 , and the plasticity index ranges from 30 to 36. According to Sowers and Sowers (1970), $\mathrm{PI}>31$ is high. Soil samples SB3, SB4, SB8, and SB9 from Ajali sands are coarse-grained sand that is not plastic, has a coefficient of permeability ranging from $2.8 \times 10^{-4}$ to $3.2 \times 10^{-4} \mathrm{~cm} / \mathrm{s}$, cohesion 10 to $18 \mathrm{kpa}$. The angles of internal resistance range from $24^{\circ}$ to $26^{\circ}$, indicating very loose compaction. Soil samples SB5 and SB10 lithological units are silty-clay with a coefficient of permeability of $4.6 \times 10^{-4}$ to $4.8 \times 10^{-4} \mathrm{~cm} / \mathrm{s}$, the cohesion of 45 to 46 $\mathrm{kpa}$, and angle of internal resistance of $37^{\circ}$ to $40^{\circ}$ indicating dense compaction. The plastic limits for SB5 and SB10 ranges from 35 to 36, liquid limit 76, and a plasticity index range of 40 to 41 . From the soil analysis, plasticity index of 40 in the study area depicts high plasticity. SB5 and SB10 have a very high liquid limit value of 76, and this conforms to Bell (2007) classification of clays in terms of liquid limits which states that values ranging from 70 to 90 are very high plasticity.

\section{Discussion}

Causes and negative impacts of landslides and gully erosions in the study area

Field and geotechnical evaluations of the soils of the study area revealed that the high elevation and a steep slope and the geotechnical properties of the soils are the initial conditions that initiated landslides and gully developments in the study area; hence, the large lateral extents, widths, and depths of the gullies. A very loose to lose compaction of the soils increases its susceptibility to erosion and landslides. The study area was influenced by high rainfall, surface water diversion, and human activities as well as socio-cultural activities. The slopes of gullies and landslides are covered with green vegetation during the rainy season. During the dry season the slopes of gullies and landslides are almost entirely bare due to overgrazing and drought during this season. Intense rainfall/excess run-off and soil erosion during the rainy season in the study area weakens the slopes by detaching the lateral base of the soil, thereby resulting in further steepening of the slopes. The digital elevation model, slope map, the land cover map generated from NASA SRTM $30 \mathrm{~m}$ data shows exactly the impact of elevation, slope, and vegetative/land cover on the principal cause, and continuous expansion of the gullies and landslides in the study area. The high permeability, low cohesion, low shear strength, frictional angles between grains, and non-plasticity of the Ajali sands are the factors responsible for initiating of slope failures, cracks, fractures, and 


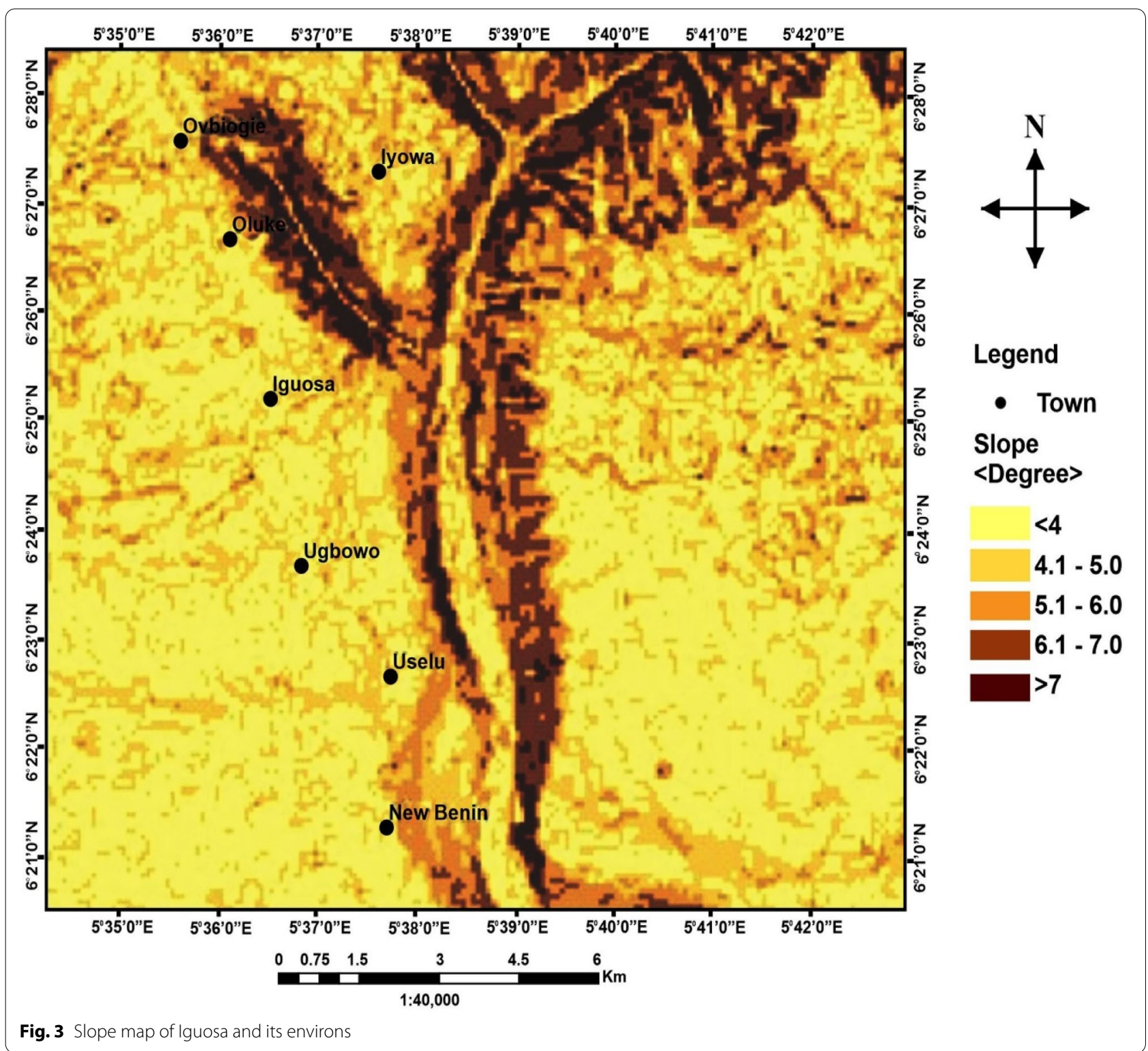

slopes of various degrees in the study area. The high permeability values show that the Ajali sands units SB3, SB4, SB8, and SB9 in the study area transmit enough volume of water into the underlying high plasticity and low permeability SB5 and SB10 (silt/clay) layers during heavy rainfall, run-off, and infiltration processes. A high pore-water pressure is developed within the Ajali sand-clay boundary. This will lead to the expansion of the clay layers (Fig. 7a), and an upward force is created on the overlying coarse sand to medium sand units as well as swollen, shrinking, and sliding activities. This alternating sequences of swelling and shrinking of the clay layer during wet and dry seasons also contributed to the initiation of the multiple slope failures, debris soil slide (Fig. 6c), and gully development in the study area. It also results in the development of new steep slopes at the base of the Ajali sands and other landslide activities in the study area. In addition to the very low permeability of silt/ clay units (SB5, SB10) that separates the sand units in the study area, the silt/ clay units (SB5, SB10) function as the gliding planes (Fig. 8a, b) that are responsible for several landslides in the study area. Inadequate drainage systems in the study area (Fig. 7b) cannot withstand the excess run-off during the rainy seasons. The excess water flow is trapped in narrow concentrated streams, which later create wide erosive channels in the earth's surfaces, thereby creating gullies of various forms, scales, and different sizes. Over four hundred and thirty-two houses, farmlands, and other physical properties have been damaged and abandoned in 


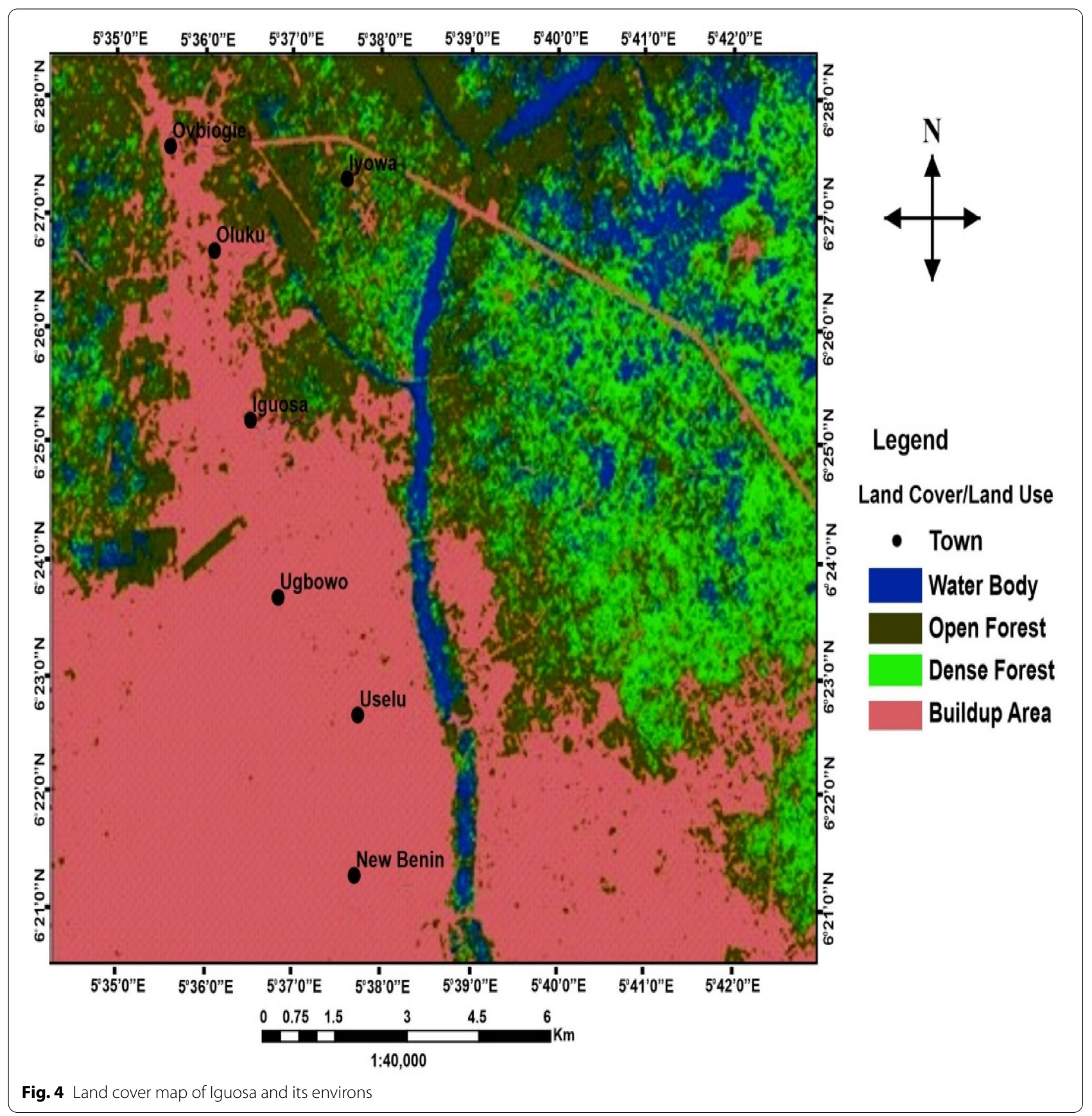

the study area (Fig. 9a). The road leading to various homes and farmlands has been negatively affected by landslides and gully erosions in the study area (Fig. 9b).

The mechanism of landslides and gullies in the study area revealed that high intensity of the torrential rains during the peak of the rainy seasons (May-September), is a major contributing factor to initiating of gullies and landslides activities. In the study area, the Ajali sand is bounded at the top by lateritic soil and below by thin layers of clay/silt soil. The high permeability values of these soils show that the Ajali sand units in the study area transmit enough volume of water to the underlying (silt/clay layers) during the period of raining season. Within this sand-clay boundary, a high pore-water pressure is developed. This excess water from rainfall will be released between the Ajali sand and clay units causing swelling of clay. The increase in the volume of water will create an upward force on the overlying 


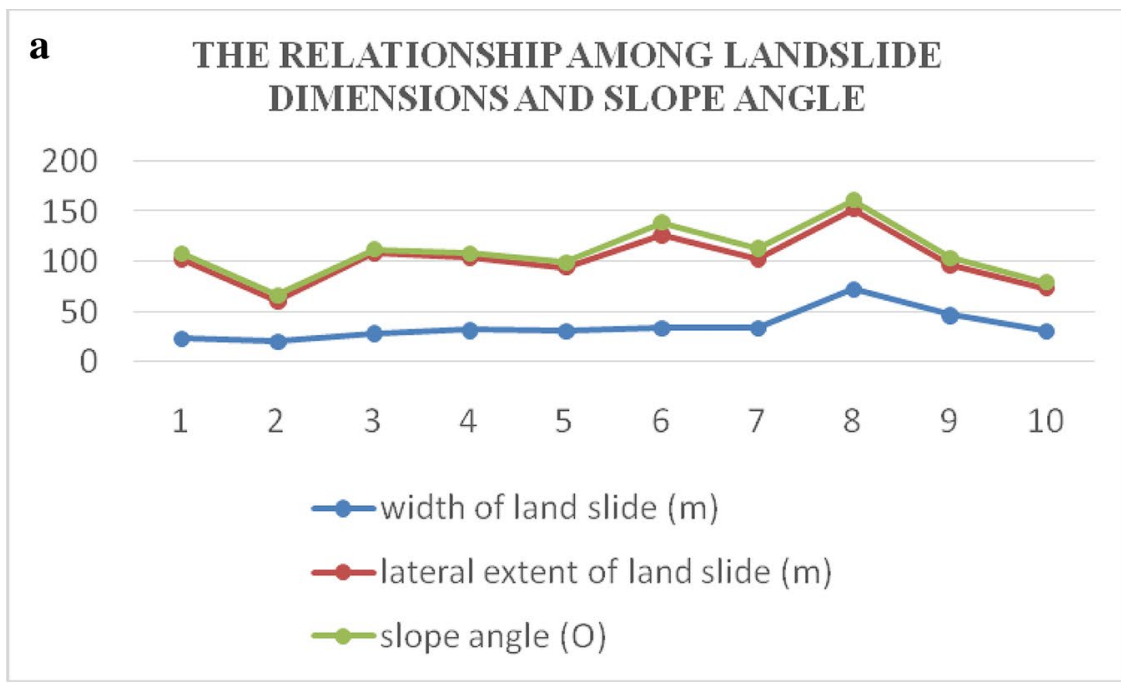

\section{b}

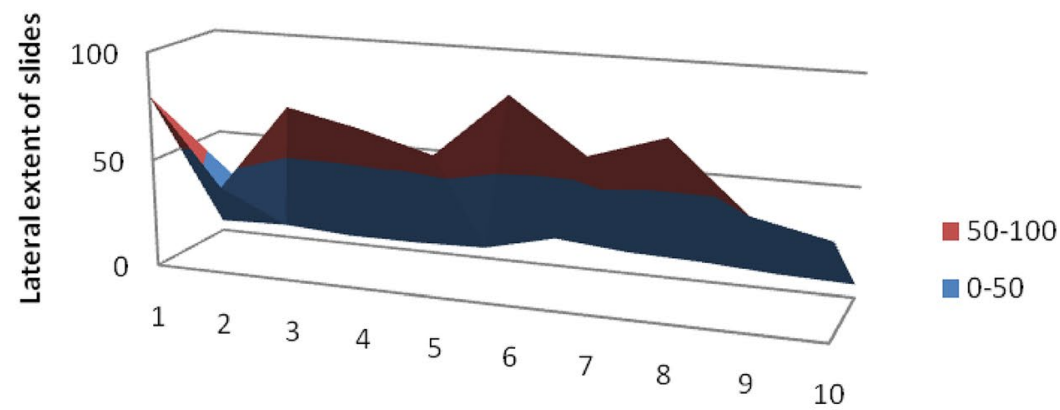

Slope Angles

\section{c SLOPE PATTERN IN THE STUDY AREA}

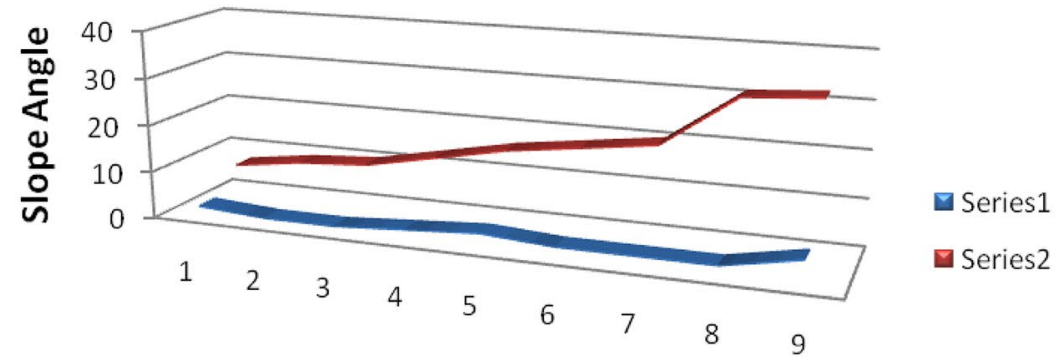

Land surface

Fig. 5 a Plot of dimensions of landslides ( $m$ ) against slope angles of the landslide. $\mathbf{b}$ 3D surface view of lateral angles versus slope angles of the landslide in the study area. $\mathbf{c}$ Slope pattern of the sliding in the study area 


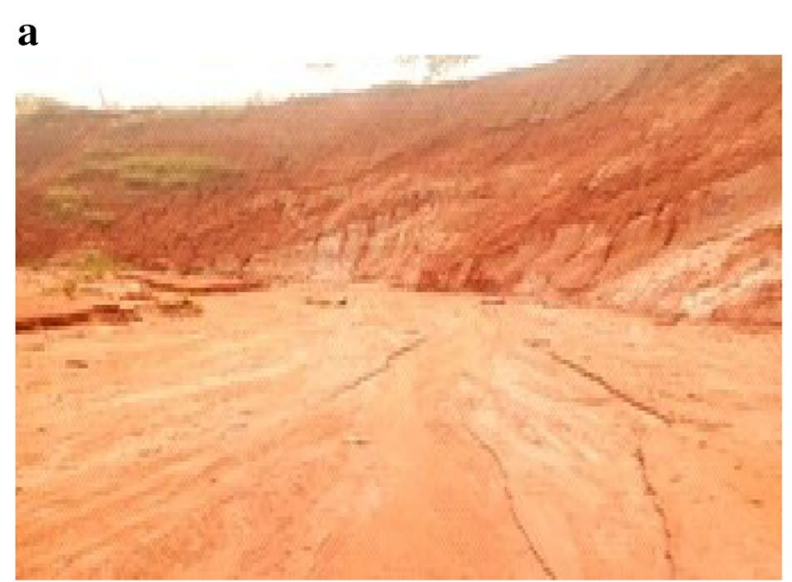

b

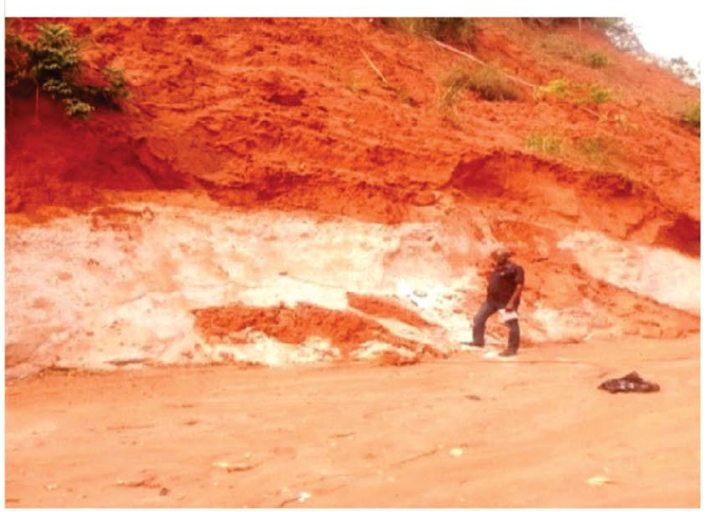

\section{c}

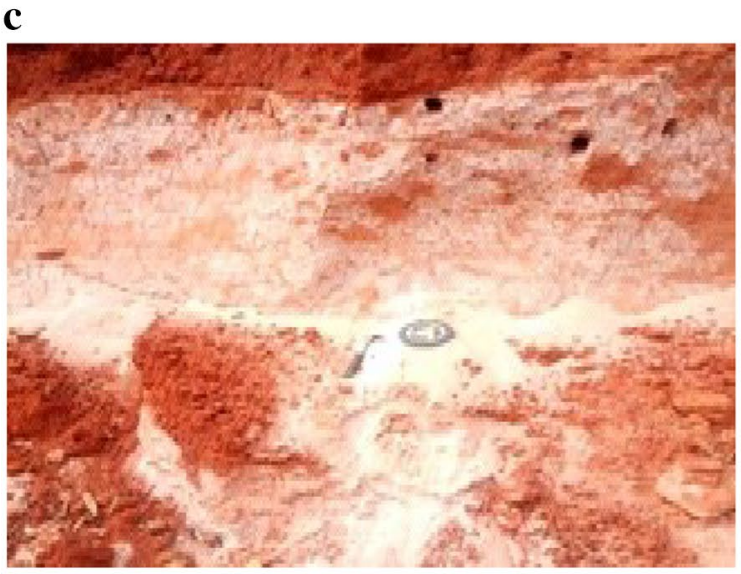

d

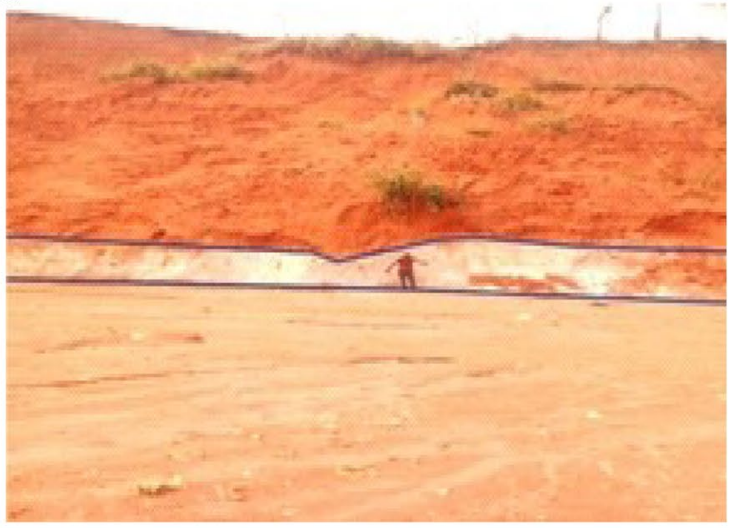

$\mathbf{e}$

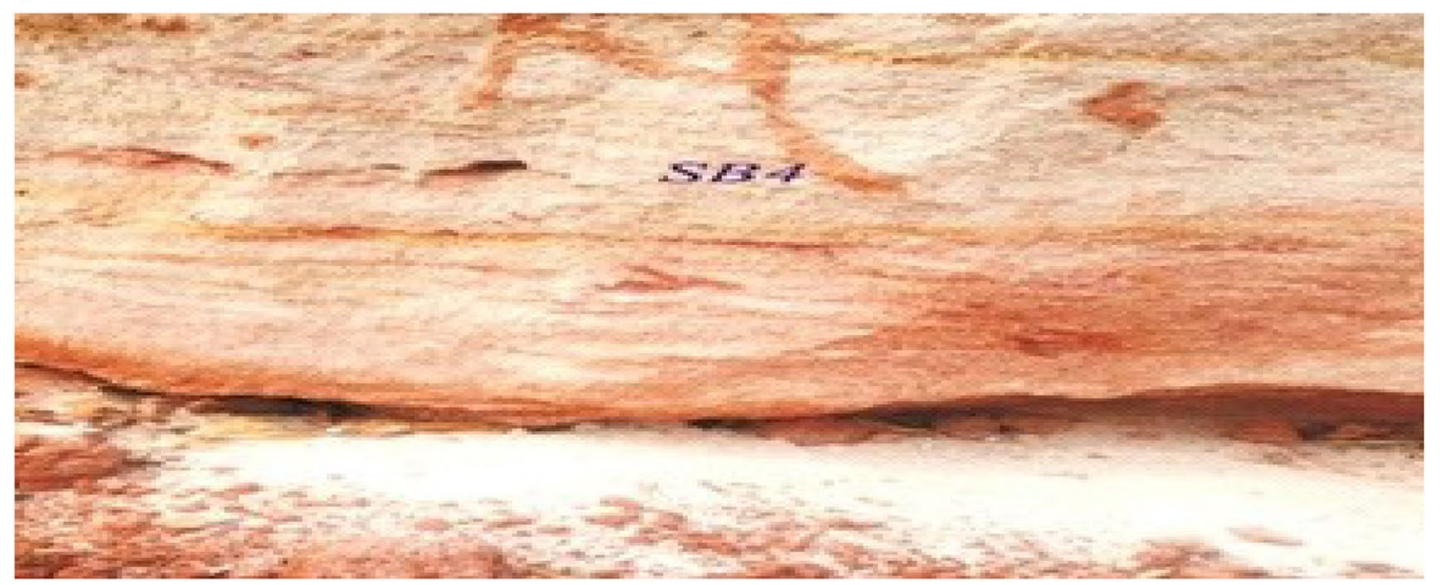

Fig. 6 a Landslide at the study location (photo by Aigbadon). b Lateral soil spread in the study area (photo by Aigbadon). c Soil debris in the study area (photo by Aigbadon). $\mathbf{d}$ Ajali Sands with thickness of about $2.5 \mathrm{~m}$ marked blue in the study area (photo by Aigbadon). e Ajali sands (SB4) in the study area (photo by Aigbadon)

coarse Ajali sand with very low plasticity. As a result of seasonal changes (wet and dry), the clay material experiences swelling and shrinking. This continuous alternation of swelling and shrinking of the clay layer beneath the Ajali sand initiates cracks, fractures which pave the way for weathering of the Ajali sands and clay 


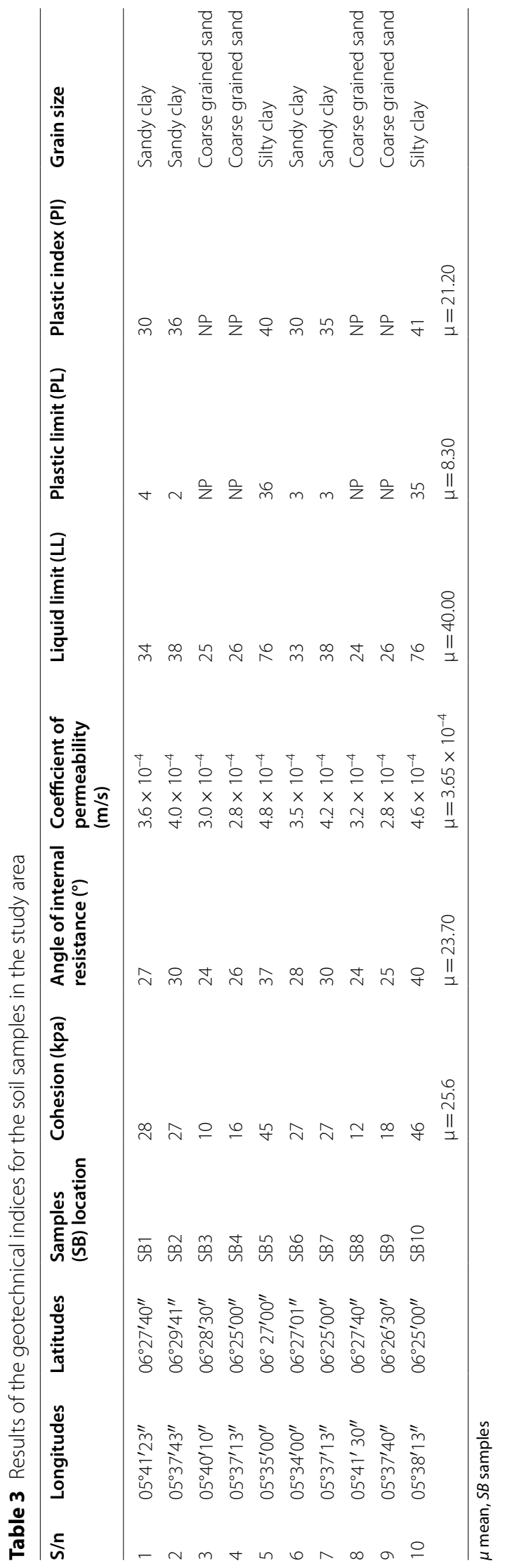




\section{$\mathbf{a}$}

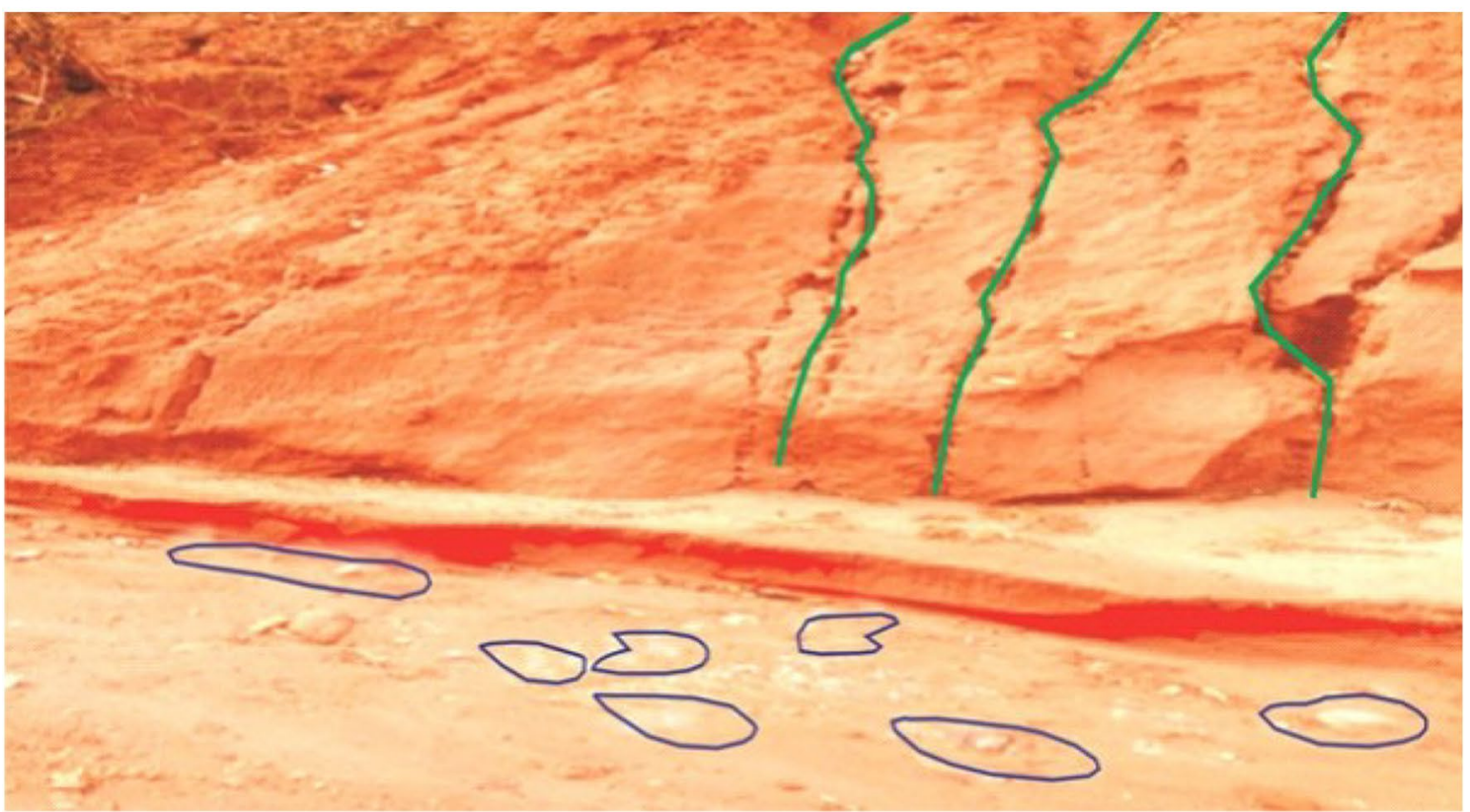

b

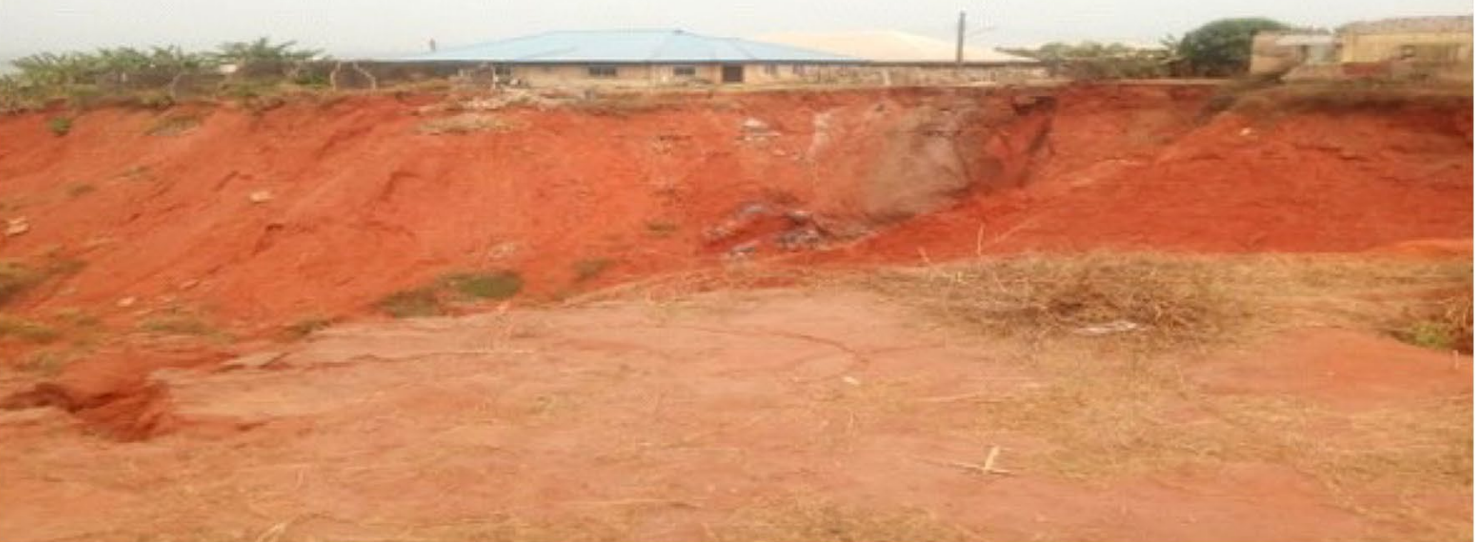

Fig. 7 a Cracks and fractures zones marked in green (photo by Aigbadon). b Surface water diverted to the landslides area couple with the poor drainage system (photo by Aigbadon)

material at the base. Subsequent weathering and mass soil sliding are as result of the weighted overburden laterite resting on the loosely compacted Ajali sands whose lateral base has been removed by erosion. The seepage-associated mechanism is also narrowed to cracks, burrows, and root holes. The development of gully channels interacts with the drainage of the intergully area through the gully beds and banks, redirecting surface and subsurface run-off which affects shallow landslides and gully erosion. Gulling infilling rates and the impacts of gully erosion in sediment yield contribute to landscape evolution (Fig. 10). 


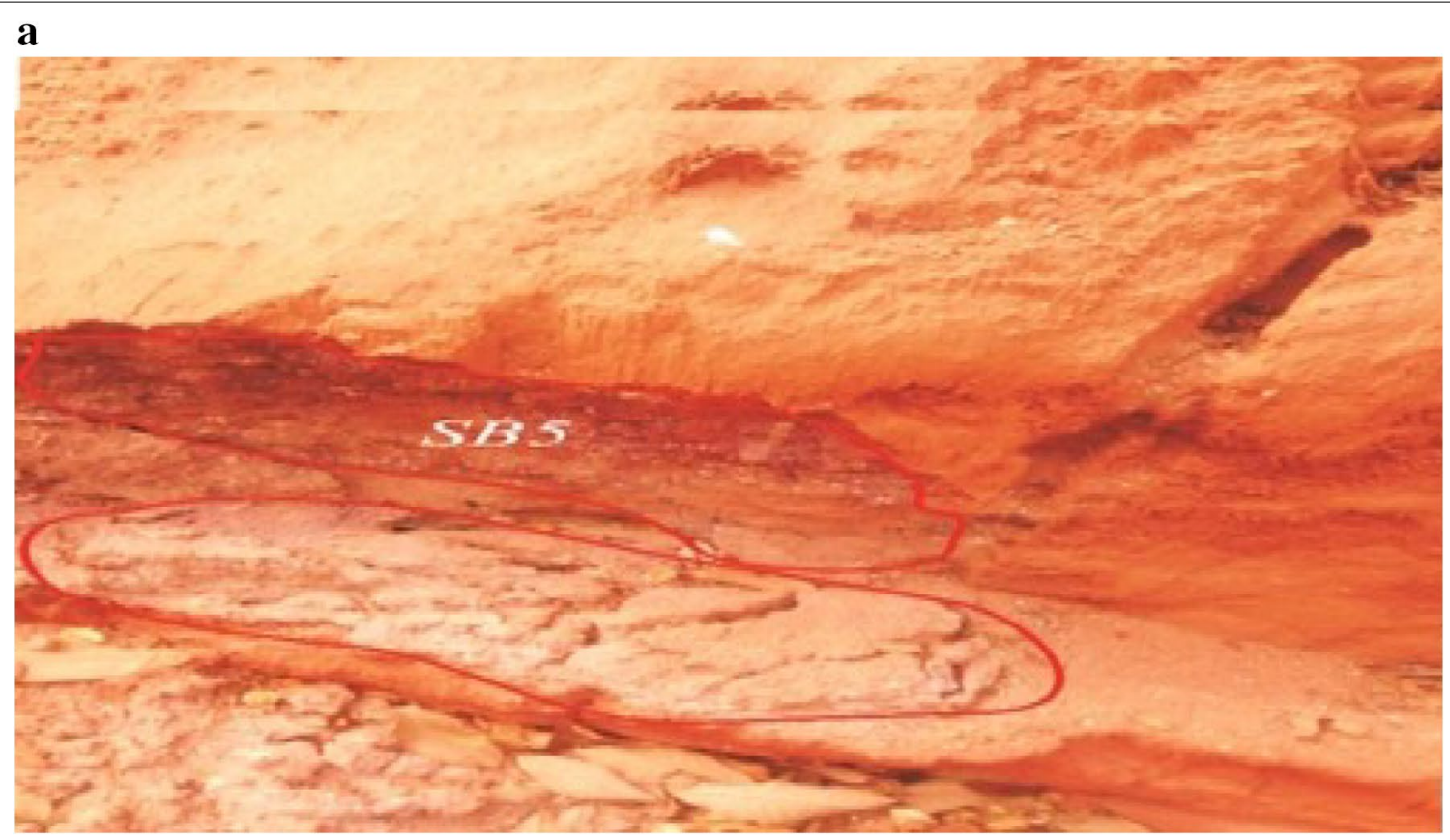

$\mathbf{b}$

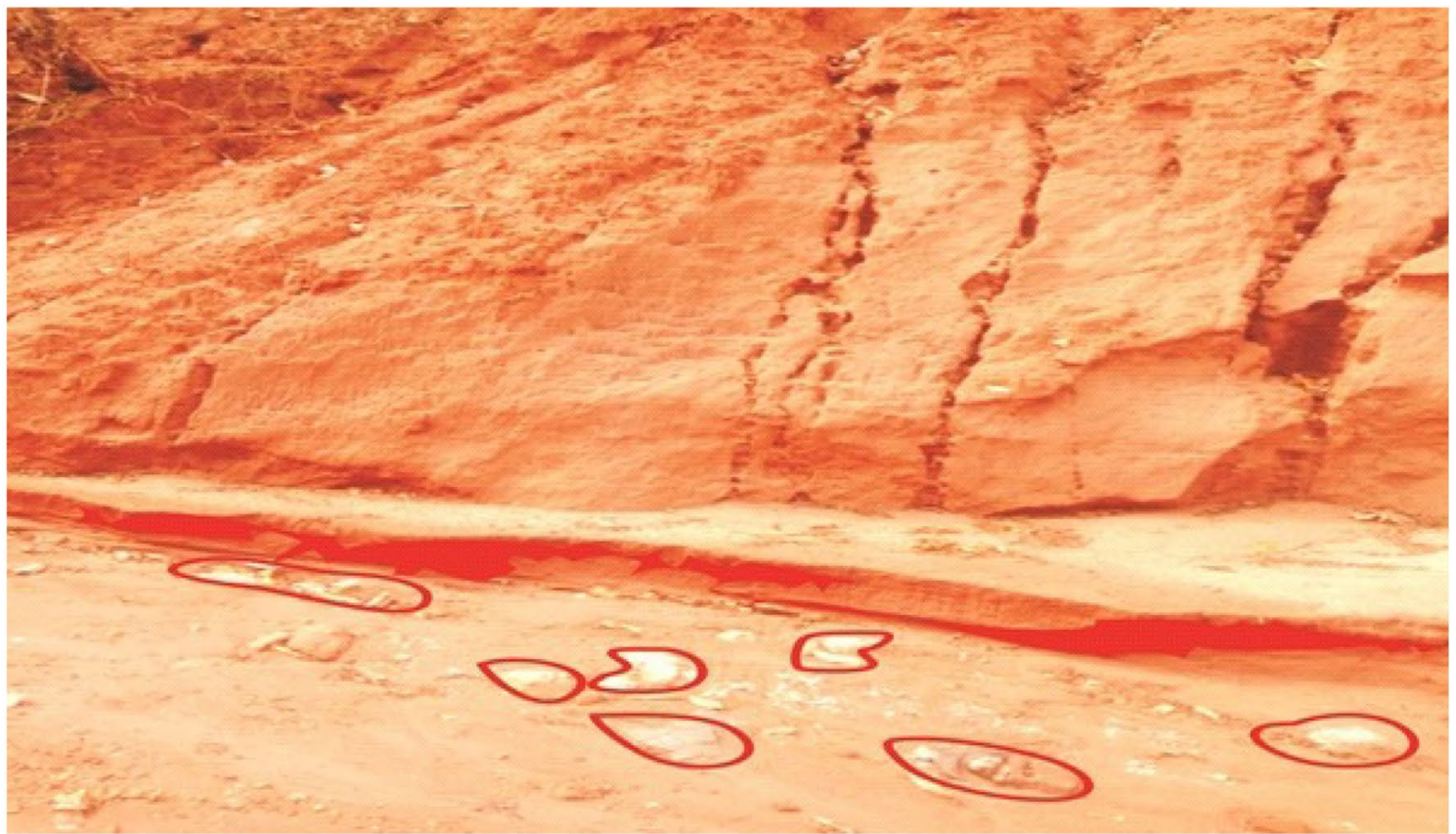

Fig. 8 a Shale/clay materials (SB5) acting as gliding surface in the study area (photo by Aigbadon). b Weathered shale/clay materials on the flood in the study area which act as the sliding plane in the affected areas (photo by Aigbadon)

Following those key findings, improving the drainage control and slope flattening will reduce the weight of the mass tending to slide and increase the resistance to sliding and hence increases the stability as recommended by (Egboka et al. 2019). The landslide areas should be covered with impermeable layers/materials and diverting the surface water away from the landslide areas. Gray and Sotir (1996) employed biotechnical slope stability method for slope failures and gully erosion problems. Such method should also be deployed in the study area to 


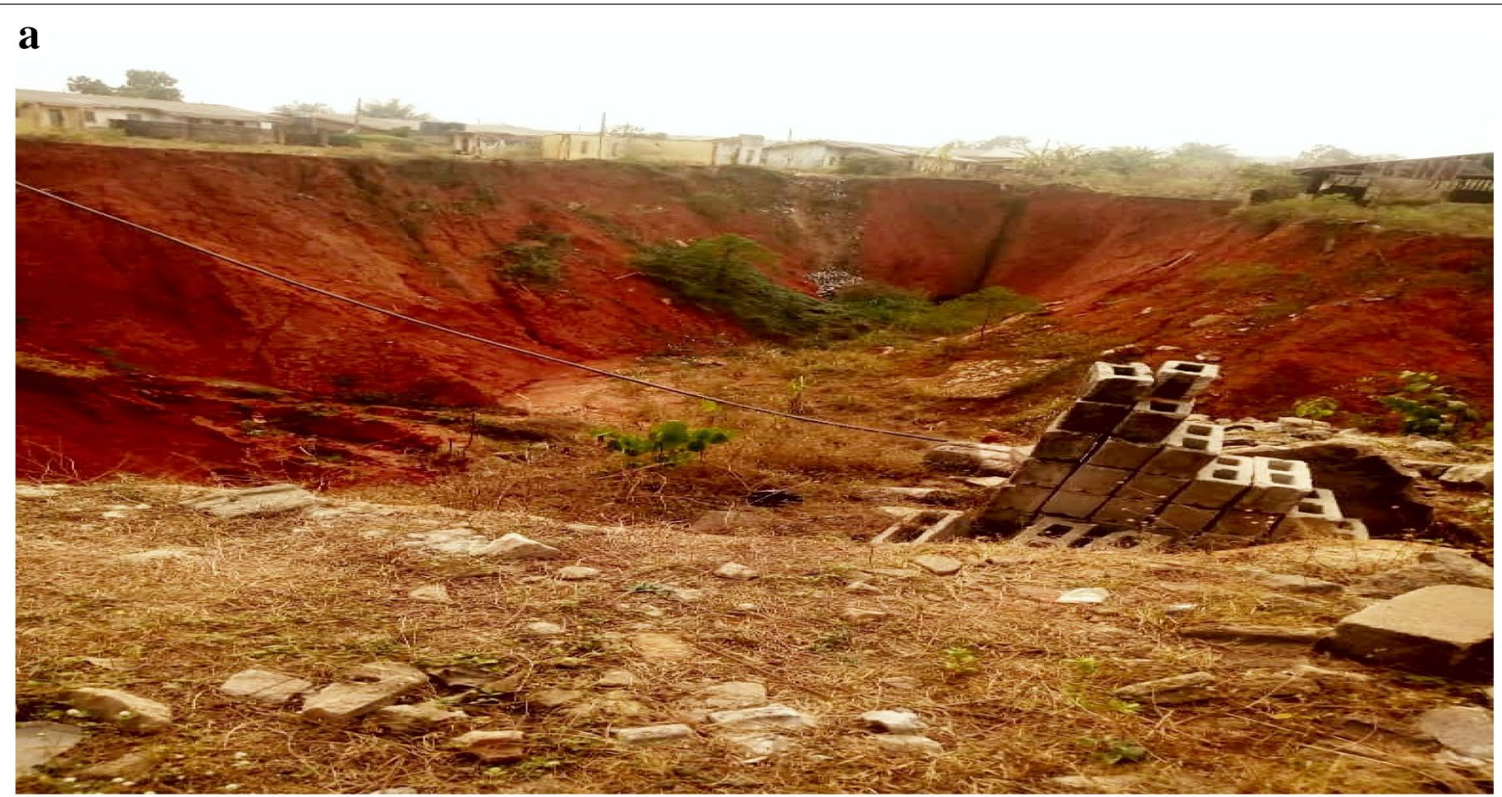

b

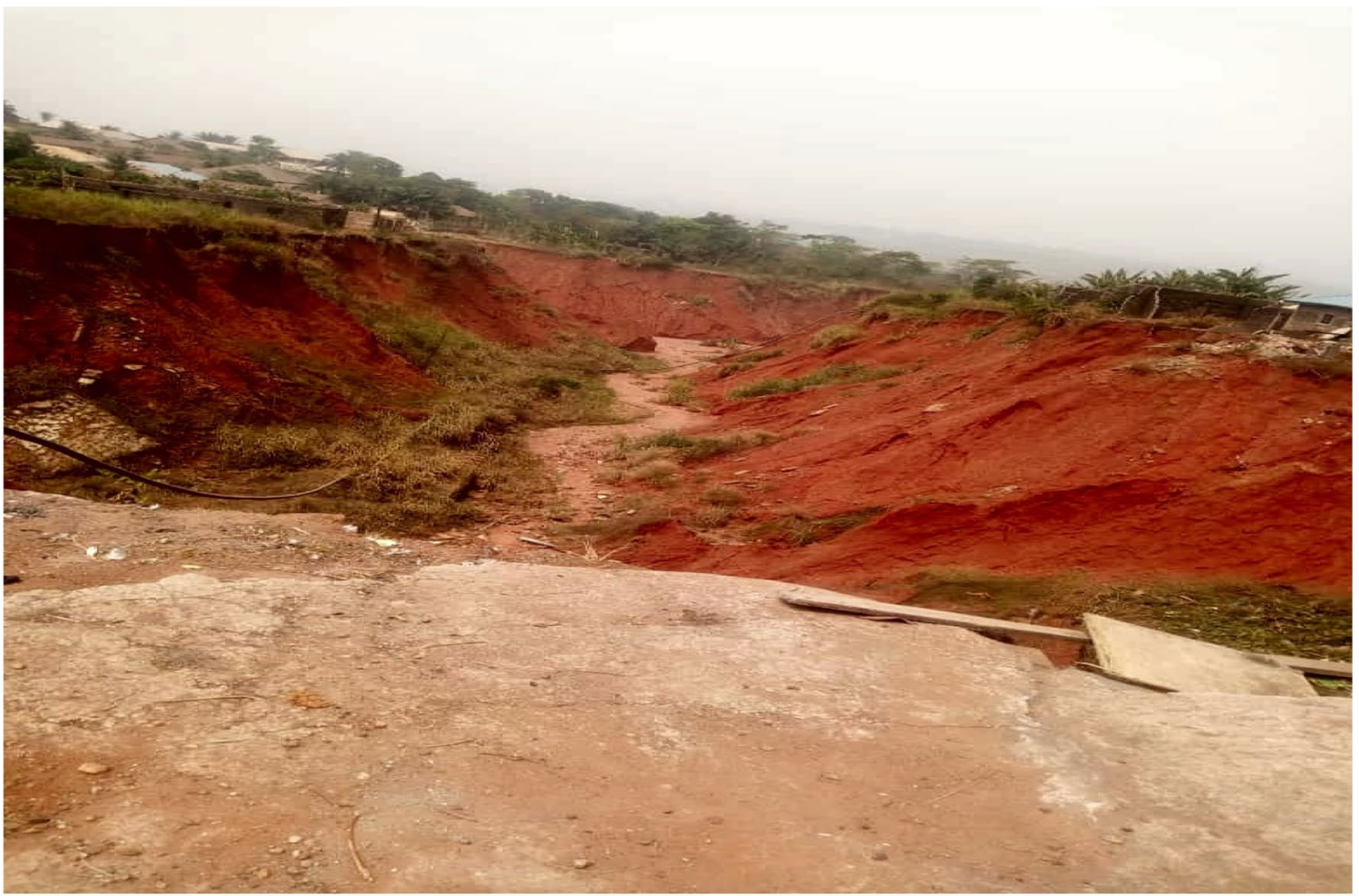

Fig. 9 a Landslide on Iguosa area threatening lives and properties in the study area. b The road leading to various homes in the study area have be truncated by erosional activities (photo by Aigbadon)

avert and stop slope failures and erosion problems. Afforestation and re-vegetation of different resistance tree species should be planted on the sloping landscape. Construction of gravity and earth dams should be done to channel the flood, and this will help reduce the velocity of inflows and convey a large inflow of water away from different catchment areas around Iguosa and its surroundings into nearby natural basins or neighbouring Okhoro 


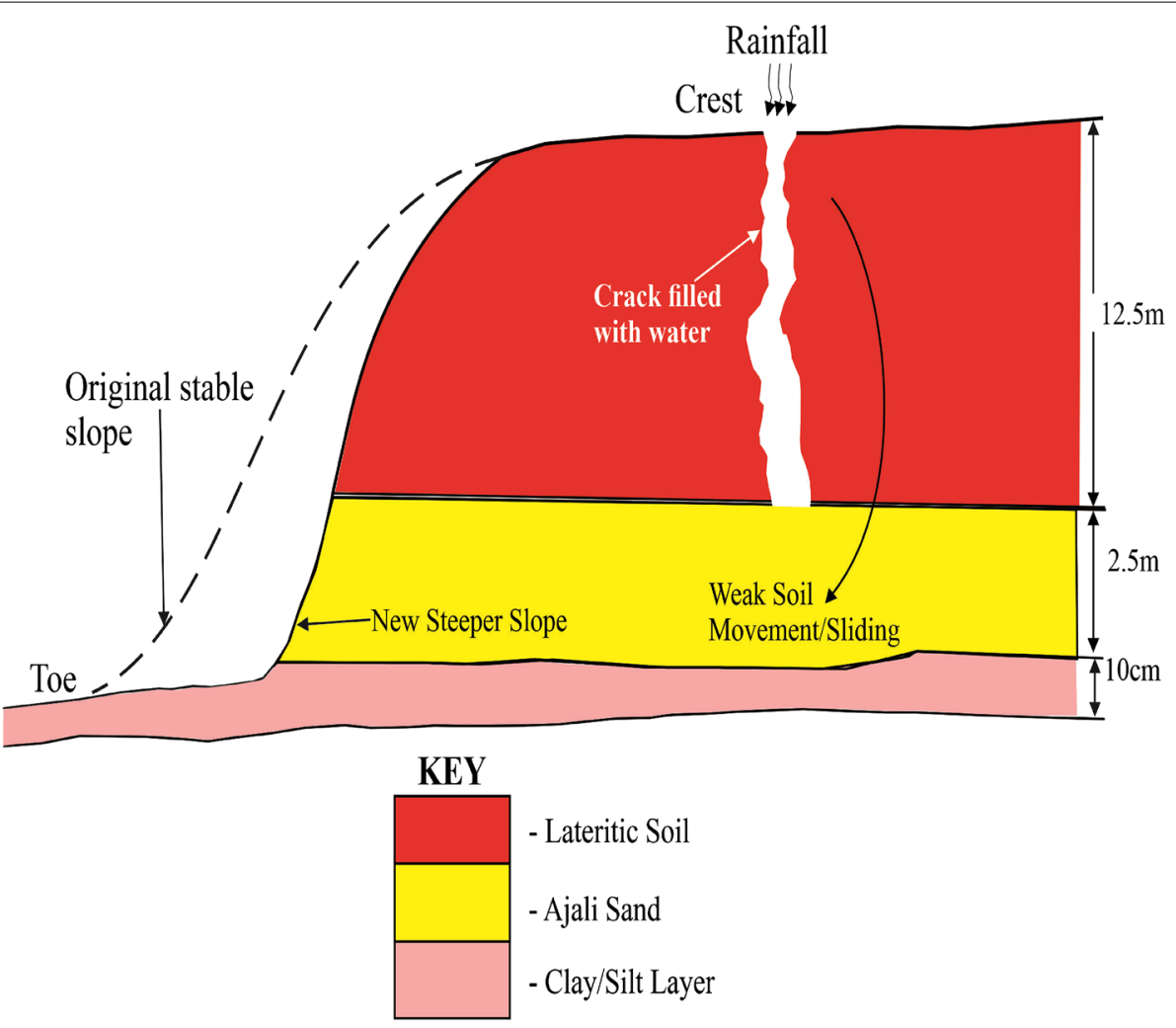

Fig.10 The mechanism of landsliding and gullies in the study area

River. Federal, State, and Local governments should enact laws to prevent the erection of structures in landslideprone areas. Adopting these recommended mitigation measures will go a long way in reclaiming the affected lands, and solving the problems of failed slopes, and continuous expansion of landslide and gully erosion hazards in the study area.

\section{Conclusions}

The origin, associated mechanisms, and effects of landslides and gully hazards have been evaluated in Iguosa and its environs. Field observation reveals that the intense and prolonged rainfall, geomorphological characteristics, weakly developed structure, high slope instability, improper use of land, and the steepness of the slope, contributed to the origin of landslides and gully erosions in the study area. The unconsolidated nature of the soil, less cohesion, high permeability, and weak plasticity of the soil that occurs under and above the clay lithological units also contributed to landslide and gully erosion. Over four hundred and thirty-two houses, farmlands, and other physical properties have been damaged and abandoned. This study has recommended effective and efficient mitigation measures to tackle this menace by covering the landslide areas with impermeable layers/ materials, diverting surface water away from the landslide areas, enacting laws to prevent the erection of structures on landslide-prone areas, sound drainage systems, the use of biotechnical slope and bioengineering methods.

\section{Abbreviations}

Kpa: Kilopascal; K: Permeability; LL: Liquid limit; PL: Plastic limit; PI: Plasticity index; NP: Non-plastic; M: Meters; CM: Centimeter; $\mu$ : Mean; SB: Soil samples; Secs: Seconds.

\section{Acknowledgements}

I acknowledged Mr. Stanley Ajike for his assistance in generating the maps used in this study.

\section{Authors' contributions}

GOA: he led the team for the field investigation/mapping, data collection, data analysis, and drafting of the manuscript. AO, EOA: he supported the field investigation, data collection, data analysis, and writing of the manuscript. All authors read and approved the final manuscript.

\section{Funding}

This research work did not receive grants/funds from any agency, institution, or individual.

\section{Availability of data and materials}

Data and materials generated and analysed are available in this research work. 


\section{Declarations}

Ethics approval and consent to participate Not applicable.

\section{Consent for publication}

Not applicable.

\section{Competing interests}

The authors declare that they have no competing interests.

\section{Author details}

'Department of Geology, Faculty of Sciences, Federal University Lokoja, Lokoja, Kogi, Nigeria. ${ }^{2}$ Department of Geological Sciences, Faculty of Physical Sciences, Nnamdi Azikiwe University, Awka, Anambra, Nigeria.

\section{Received: 4 April 2021 Accepted: 2 July 2021}

Published online: 19 July 2021

\section{References}

Akujieze CN (2004) Effects of anthropogenic activities (sand quarrying and waste disposal) on urban groundwater system and aquifer vulnerability assessment in Benin City, Edo State, Nigeria. Ph.D Thesis, University of Benin, Benin City, Nigeria

Ayodele OS, Olayanju GM, Adeosun OE (2020) Geological assessment of landslide occurrences in Okemsi area, Southwestern Nigeria. Am J Environ Eng 10(1):13-19. https://doi.org/10.5923/j.ajee.20201001.03

Bell FG (2007) Engineering geology, 2nd edn. Elsevier, London, pp 207-248

Brand EW, Premchitt J, Phillipson HB (1984) Relationship between rainfall and landslides. In: Proceedings of the 4th inter-national symposium on landslides, vol 1. BiTech Publishers, Toronto, pp 377-384.

British Standard (BS) (1990) Methods for testing soils for civil engineering purposes. British Standard Institution, London

British Standard 1377.5 (1990) Compressibility, permeability, and durability tests. Determination of permeability by the constant Head Method. British Standard Method of test for Civil Engineering purposes, Part 5

Chen HS, Liu JW, Zhang W, Wang KL (2012a) Soil hydraulic properties on the steep karst hill slopes in northwest Guangxi. China Environ Earth Sci 66(1):371-379

Chen XQ, Li Y, Gao Q, Jia ST (2012b) Distribution characteristics of geo-hazards in Ganxi Valley after the Wenchuan earthquake. Environ Earth Sci 65(4):965-973

Cruden DM, Varnes DJ (1996) Landslide types and processes. In: Turner AK, Schuster RL (eds) Special report 247: landslides investigation, mitigation. National Research Council, Transportation Research Board, Washington, DC, pp 36-75

Egboka BCE, Okpoko El (1984) Gully erosion in the Agulu-Nanka region of Anambra State, Nigeria. Challenges in African hydrology and water resources. In: Proceedings of the Harare symposium, July 1984. IAHS Publication, Oxford, no. 144.

Egboka CE, Akudo EO, Hycienth ON (2019) Gully erosion and landslides in southeastern Nigeria: causes, consequences, and control measures. Glob J Eng Sci 2(4):1-11

Evamy DD, Haremeboure J, Kamierling WA, Knaap WA, Molly PH, Rowland PH (1978) Hydrocarbon habitats of tertiary Niger delta. Assoc Am Petrol Geol Bull 62:1-39

Fukuoka M (1980) Landslides associated with rainfall. Geotech Eng 11:1-29

Gray DH, Leiser AT (1982) Biotechnical slope protection and erosion control. Van Nostrand Reinhold Company, New York

Gray DH, Sotir RB (1996) Biotechnical and soil bioengineering slope stabilization-a practical guide for erosion control. Wiley, New York

Guzzetti F, Carrara A, Cardinali M, Reichenbach P (1999) Landslide hazard evaluation a review of current techniques and their application in a multi-scale study, Central Italy. Geomorphol 31:181-216

Highland LM, Bobrowsky P (2008) The landslide handbook-a guide to understanding landslides, vol 1325. U.S. Geological Survey Circular, Reston, p 129
Igwe O (2015) The geotechnical characteristics of landslides on the sedimentary and metamorphic terrains of Southeast Nigeria, West Africa. Geoenviron Disasters 2(1):1-14. https://doi.org/10.1186/s40677-014-0008-z

Igwe O, Fukuoka H (2010) Environmental and socioeconomic impact of erosion in Nigeria, West Africa. Int J Eros Control Eng 3(1):102-109

Igwe O, Una CO (2019) Landslide impacts and management in Nanka area, Southeastern Nigeria. Geoenviron Disasters 6(5):1-12. https://doi.org/10. 1186/s40677-019-0122-z

Igwe O, Mode W, Nnebedum O, Okonkwo I, Oha I (2013) The analysis of rainfall-induced slope failures at Iva Valley area of Enugu State. Environ Earth Sci. https://doi.org/10.1007/s12665-013-2647-x

Ikhile C (2015) Geomorphology and hydrology of Benin Region Edo State, Nigeria. Int J Geosci 7:144-157

Ishaque F, Hoque MN, Rashid MA (2010) Determination of plastic limit of some selected soils using the rolling device. Prog Agric 21(1\&2):187-194

Iverson RM (2000) Landslide triggering by rain infiltration. Water Resour 36(7):1897-1910

Jakob M, Holm K, Lange O, Schwab JW (2006) Hydrometeorological thresholds for landslide initiation and forest operation shutdowns on the north coast of British Columbia. Landslides. https://doi.org/10.1007/ s10346-006-0044-1

Ko CK, Chowdhury R, Flentje P (2005) Hazard and risk assessment of rainfallinduced land sliding along a railway line. Q J Eng Geol Hydrogeol 38:197-213

Kogbe CA (1976) Paleogeographic history of Nigeria from Albian Times. In: Kogbe CA (ed) Elizabeth Publishers, Lagos, Nigeria, pp 237-252

Lee CC, Zeng LS, Hsieh CH, Yu CY (2012) Determination of mechanisms and hydrogeological environments of Gangxian lane landslides using geoelectrical and geological data in Central Taiwan. Environ Earth Sci 66(6):1641-1651

Li AG, Yue ZQ, Tham LG, Lee CF, Law KT (2005) Field-monitored variations of soil moisture and matric suction in a saprolite slope. Can Geotech J 42:13-26

Munch JH, Douglas RW (1985) Equipment and methodology of sampling and testing cohesionless sediments. Ground Water Monit Rev, 38-42

Msilimba G, Holmes P (2010) Landslides in the Rumphi district of northern Malawi: characteristics and mechanisms of generation. Nat Hazards 54(3):657-677

NiMet (2010) Nigeria Climate Change Review Bulletin, Nigeria Meteorological Agency, http://www.nimetng.org

Obaje NG, Wehner G, Scheeder G, Abubakar MB, Jauro A (2004) Hydrocarbon productivity of Nigeria's Inland Basins: from the Viewpoint of organic geochemistry and organic petrology. AAPG Bull 88:325-353

Ocheli A, Ovie OB, Aigbadon GO (2021) Geology and geotechnical investigations of part of the Anambra Basin, southeastern Nigeria: implication for gully erosion hazards. Environ Syst Res 10:23. https://doi.org/10.1186/ s40068-021-00228-2

Ogbukagu IM (1976) Soil erosion in the northern parts of Awka-Orlu uplands, Nigeria. Nigerian J Min Geol 13:6-19

Okagbue CO (1986) Gully development and advance in a rain forest of Nigeria In: Proc. 5th Congr. Int. Assoc. Eng. Geol. Buenos Aires, 1999-2010.

Okagbue CO (1992) The 1988 Nanka landslide, Anambra state, Nigeria. Bull Int Assoc Eng Geol 46(1):79-87

Omon EJ, Ogheruemusua GJ (2014) Evaluating soil erosion in the Benin metropolis, Edo State. Int J Phys Sci 2(3):38-45

Perucca LP, Yanina M, Angillieri E (2009) Evolution of a debris-rock slide causing a natural dam: the flash flood of Rio Santa Cruz, Province of San JuanNovember 12, 2005. Nat Hazards 50:305-320

Reyment RA (1965) Aspects of the Geology of Nigeria. Ibadan University Press, Ibadan

Sassa K, Wang G, Fukuoka H, Wang FW, Ochai T, Sugiyams ST (2004) Landslide risk evaluation and hazard mapping for rapid and long-travel Landslides in urban development area. Landslide 1(3):221-235

Short KC, Stauble AJ (1967) Outline of the geology of Niger Delta. Assoc Am Petrol Geol Bull 51:761-779

Sikdar PK, Chakraborty S, Adhya E, PrabirKumar P (2004) Land use/land cover changes and groundwater potential zoning in around Raniganj coal mining area, Bardhhaman District, Western Bengal-GIS and Remote Sensing Approach. J Spat Hydrogeol 4(2):1-2

Sohne W (1953) Reibung and fohasionbeineoAckerboden (friction and cohesion of agricultural soils). GrundiLand Tech 5:64p 
Sowers GB, Sower GE (1970) Introductory soil mechanics and foundations, 337. Macmillan Book Publishing Company, London

Surendra R, Sajeev KB (2017) Roles of geotechnical properties of soils on civil engineering structures. Resour Environ 7(4):103-109. https://doi.org/10. 5923/j.re.20170704.03

Ukhurebor KE, Abiodun Cl (2018) Variation in annual rainfall data of fortyyear (1978-2017) for south-south, Nigeria. J Appl Sci Environ Manag 22(4):511-518

Varnes DJ (1978) Slope movement types and processes in landslide analysis and control. In: Clark M (ed) Trans. Res. Board, National Academy of Science, National Res. Council, Washington DCSpecial Rep. vol 176, pp $11-13$

Wang FW, SassaK WG (2002) Mechanism of a long-run out landslide triggered by August 1998 heavy rainfall in Fukushima prefecture. Jpn Eng Geol 63(1-2):169-185
Weber KJ, Daukoru EM (1978) The role of faults in hydrocarbon migration and trapping in Nigeria growth fault structures. In: 10th annual offshore technology conference proceedings, vol 4, pp 2642-2653

Wieczorek GF (1996) Landslides triggering mechanisms. In:Turner AK (ed) Landslides investigation and mitigation. National Research Council, Transportation Research Board, Washington, pp 76-90

Yalcin A (2007) Environmental impacts of landslides: a case study from East Black Sea region, Turkey. Environ Eng Sci 24(6):821-833

\section{Publisher's Note}

Springer Nature remains neutral with regard to jurisdictional claims in published maps and institutional affiliations.

\section{Submit your manuscript to a SpringerOpen ${ }^{\circ}$ journal and benefit from:}

- Convenient online submission

- Rigorous peer review

- Open access: articles freely available online

- High visibility within the field

- Retaining the copyright to your article

Submit your next manuscript at $\boldsymbol{\nabla}$ springeropen.com 